\title{
A SURVEY ON THE USE OF E-COMMERCE BY BRAZILIAN COMPANIES
}

\author{
Gilberto Dias da Cunha \\ José Luis Duarte Ribeiro \\ Industrial Engineering Department \\ Federal University of Rio Grande do Sul, BRAZIL \\ gcunha@ufrgs.br \\ ribeiro@ufrgs.br
}

\begin{abstract}
This work presents a preliminary analysis on the status of the application of ecommerce and e-business technologies at Brazilian companies. The results from a market survey on the use of e-commerce will be introduced along with a simplified characterization of the companies' business process.

Keywords - Internet, e-business
\end{abstract}

\section{INTRODUCTION}

For a country intending to get integrated into the globalization process, it is fundamental to be in touch with the new trends regarding the commercialization of products. There is a major discussion being carried on in Brazil and other developing countries (DC's) presently on this subject (Brito, 1999). One of the main topics regarding this discussion is the possibility of achieving the integration by using the Internet. On the other hand it is generally accepted the effective achievement of the e-commerce technology is a key factor to the successful establishment of the virtual enterprises nowadays.

This work aims to evaluate the situation regarding the implementation and use of the e-commerce technology by some typical Brazilian companies as a means of integrating the company, its clients and its suppliers. Upon this context, it will be made a short description on the use of the specific technologies related to the ecommerce and the e-business by the local companies as much as an analysis on the situation of the companies cases (companies ranging from different branches and sizes were surveyed).

Taking a first glance at this specific market in Brazil, let us take a look to some information given by the IBOPE (one of the most important Brazilian market surveys institute) and by the company owner of Cadê? (a local search-engine provider similar to the Yahoo! and the Altavista). According to it, $87 \%$ of the internauts earn more than 10 times the minimum wage (about US\$ 75) - which must be compared to the Brazilian overall market where $62 \%$ of the population earns less than 5 times the minimum wage. The IBOPE points that $72 \%$ of the internauts use credit cards and $62 \%$ would buy goods via Internet if the services are adequate provided (Vargas, 2000). Doubtless, this is an attractive market considering the DC's conditions. 


\section{THE SURVEY}

The market survey was based on the application of a questionnaire, which was supposed to be answered mainly by the personnel of the commercial area from the companies. This questionnaire is introduced next. Basically it asks for the different ways the information is exchanged among the customers and the suppliers.

Q1. How is the information exchanged between your company and the customer?

Q2. How is the information exchanged between your company and the supplier?

Q3. Which criteria do you use to choose a supplier?

Q4. If you could check your supplier performance continuously, which information would you require to be provided?

Q5. In case the supplier is placed far away, how would you proceed?

Q6. Do you keep any kind of control on your suppliers products?

(If the answer is affirmative: How is it made? On which frequency?)

(If not: Why?)

Q7. Do you keep control on the production process along with your suppliers?

(If the answer is affirmative: How is it made? On which frequency?)

(If not: Why?)

Q8. Are the computers in your company connected by a network?

Q9. Do they have access to the Internet?

Q10. Does your company have its own homepage (site)?

(If the answer is affirmative: On which purpose do they use the Internet?)

Q11. Does your company choose your supplier via Internet?

(If the answer is affirmative: On which information should your company rely on to take decisions?)

(If not: Would you be willing to choose? What type of information would be used for this purpose?)

Q12. Would you find it useful to search a database on the Internet containing information on companies to search for clients and suppliers? Why?

Q13. Would your company be a future user of the electronic-commerce? Why?

The surveyed companies belong to several branches from both the industry and the services - all placed in the State of Rio Grande do Sul, Brazil, which is regarded as the fourth most important State from the Brazilian Federation (which comprises 26 states) from the economical point of view. The industry from this State can be considered very representative from the average situation found in the whole country industry. The spectrum of the surveyed companies is introduced next:

1st company - electrical and electronic appliances and devices branch (annual revenue of US\$ 300 million);

2nd company - metallurgical branch (more than 1000 employees);

3rd company - medical services branch (about 5000 employees);

4th company - furniture branch (about 150 employees and annual revenue about US\$ 10 million);

5th company - transport services branch (river shipping line), (about 250 employees and annual revenue about US\$ 10 million); 
6th company - shoes manufacturing branch;

7th company - food (bakery) branch (about 650 employees);

8th company - electrical and electronic components branch (about 1000

employees and annual revenue about US\$ 100 million).

\section{ANALYSIS ON THE SURVEY}

The summary of answers to the questionnaire is presented in the item 4 on a question per question basis. The analysis on the answers leads to some preliminary conclusions on the actual situation. A brief qualitative analysis on the information given by the different companies is presented next.

It was noticed the exchange of information among the companies and their clients via e-mail is quite effective for most of the companies, even though most of them considers it is still necessary to maintain the contacts performed by the salesman. This is especially important in the cases where the aspect of the product is considered a key factor denoting its quality. It was also reported the need of establishing a direct communication between the client and the company, like the use of a free "call center".

Besides, for the companies having many small clients, there is usually some representative whom makes direct contact with the client. In cases where the product and its sales condition (price, delivery and payment time) is fully previously defined or known, the sale can be made in an easy way, such as fax or e-mail. Even upon such a condition, it was reported that it is not possible to eliminate the visits from the commercial representatives as it is considered an important market strategy to demonstrate interest for the client. It was also pointed the need for an available external network (extranet) for data transmission by a industrial company as the possibility of enabling the clients to access information concerning the status of their production order was considered an important market strategy.

Today the enterprises are looking more and more for close partnerships with their suppliers, thus leading to the concept of virtual enterprising. The effective use of the e-mail as a means of communication between the company and the supplier was mentioned in the survey as a key factor to support achieving higher confidence standards concerning the information exchange. Therefore the e-mail is seen by the enterprises as a facilitator of the action between the partners.

One of the companies reported to use the Electronic Data Interchange (EDI) technology to make the information flow more agile, thus easing the synchronization among production activities of different companies. At this point it was also pointed that one of the advantages in using EDI lies on the cost reduction related to the purchase tasks.

The possibility of selecting suppliers via Internet was also searched. It was verified that the criteria used to select a supplier depend much on the kind of business the company is involved. This was so even though all companies mentioned just a few key elements to consider in the selection process (like product quality, price, the company logistics, technical capacity, shortness of delivery time and the accomplishment to the due dates). It seems that most of the companies see the search of partners via Internet as a valid practice, however, it was confirmed the need for an in-site evaluations before any kind of agreement. For instance one company referred the suppliers are evaluated based on the in-site analysis of their quality systems 
(involving inspections of the suppliers installations). This inspection is normally done by the company personnel. Two of the surveyed companies inform to consider fundamental the existence of a quality guarantee system (based on ISO 9000, QS 9000 , etc.) in their suppliers - to the extent of forcing them to obtain the certification.

The examination of the purchased product is the way chosen for all companies to control the quality of the supplied elements. As a rule, the purchase of products from a new supplier depends on testing the product. The tests applied to each product differ according to its class. For the companies from the food branch a report from an expert may be required. Some of this auditing process is performed by governmental entities according to the country laws. In the metallurgy branch, the raw material is tested to check its adequacy to the production processes.

In the case of products presenting a wide range of variability, for instance, as leather pieces, the company sends a representative to the supplier to perform the product selection. This is done because of the lack of confidence in the results of the supplier's process without adequate supervision. In other cases, it is possible to rely considerably more on the suppliers. In two manufacturers of electrical and electronic equipment and appliances, the suppliers are evaluated according to indexes figured out during the production process by the supplier itself. For those "client companies" there is no inspection at the reception of components stage but they are checked all through the assembly lines of the final products. The suppliers are evaluated every month based on those indexes (checked against the number of components effectively presenting malfunction). Every 3 months (in the first company) and 6 months (in the other one) it is made a supplier evaluation by a team comprising personnel from engineering, purchasing, manufacture and quality control.

For the companies dealing with food, it turns necessary a regular inspection on the supplier's facilities to evaluate hygiene conditions. In the specific case of this branch, there is no possibility the supplier is located far away from the client company, because the frequency the products are delivered is quite high - and generally the products are highly perishable.

Concerning the quality control of the supplier's products, the companies do it in agreement. The terms of the agreement depend on the kind of product and class of supplier. The companies perform the inspections at receiving the products. The inspection frequency varies according to the product. For instance, each batch received from nutritious products may be analyzed at the company laboratory. Companies from the food industry need to perform regular inspections on the supplier's facilities to evaluate the hygiene conditions. It was referred that there is no possibility that the supplier would be placed far away from the company as the products delivery frequency is quite high (and the products may easily perish).

The practice of parsing the production is only applied in the cases where a project is supplied to be manufactured - for instance, machines or special equipment and devices. In such a case, an engineer is sent to follow the production processes and steps. In the case of a navigation company, even the raw materials used by the supplier are kept under analysis - which was reported to be done by companies specifically hired for the service.

All the companies reported to have the access to the Internet already installed. Just one of the companies does not have a site in the Internet. It was also verified that the use of Internet is quite restricted to e-mail communication, which is mainly used to make contacts with the customers and the (already established) suppliers by sending technical information (like drawings, technical analysis and consultations). 
The access to the sites from the possible new suppliers was also referred, although it was pointed out that the purchase might only be confirmed after the tests to the products are made. Nevertheless none of the companies reported to choose the suppliers exclusively through the Internet although it is considered a way to make a first contact with them. ('The choice of a supplier depends on a series of factors which cannot be analyzed exclusively based on the information available from the suppliers homepages').

For the moment, 6 of the companies referred not to be interested in choosing suppliers via the Internet; 2 of them are already interested (and one of them sees it will be an interesting option for the future). However all of them agree that even in the future it will be necessary to test or to analyze the production in-site, keep visiting the suppliers facilities. It was mentioned that possibly the lack of appropriate hardware and telecommunications system would be an obstacle to the electroniccommerce implementation process.

All the companies agree it would be interesting to use databases provided through the Internet, for ease of consulting the information on clients and suppliers according to each industry branch. It is considered a possible source of information on technical specifications of products, suppliers and overall market information. One of the companies mentioned a magazine named 'Fornecedores' (from national circulation) which enables a similar service on purchases ('if we could count on this kind of information in the Internet, it would be much better...').

It was also mentioned that the purchase via the Internet is strongly related to the class of the products. For instance, CD's and books can be bought easily by the Internet, but clothes, perfumes, shoes, etc., i.e., products demanding to be checked in order to evaluate their suitability, are not adequate to be sold in this way.

From the surveyed companies, 4 referred to be future users of the electronic commerce. No company discarded - from the beginning - the idea of using the ecommerce, but all of them agree its implementation would suppose the existence of a culture (and of a infrastructure) still expected to be consolidated in Brazil (and maybe even abroad).

\section{THE ANSWERS TO THE QUESTIONNAIRE}

This section presents the answers to the questionnaire used in the survey. The results are summarized in tables related to each question. The tables were directly extracted from the answers to the questionnaire - except for the tables 12 and 13 which were derived from the answers to the question ' $\mathrm{Q} 11$ '. Notice the questions are labeled from ' $\mathrm{Q} 1$ ' to ' $\mathrm{Q} 13$ ' as well as the answers from each company are labeled as ' $\mathrm{C1}$ ' to 'C8'.

Table 1 - Q1: How is the information exchanged between your company and the customer?

\begin{tabular}{|l|r|r|r|r|r|r|r|r|c|}
\hline Company $>$ & C1 & C2 & C3 & C4 & C5 & C6 & C7 & C8 & Total \\
\hline Phone & $\mathrm{x}$ & $\mathrm{x}$ & $\mathrm{x}$ & $\mathrm{x}$ & $\mathrm{x}$ & $\mathrm{x}$ & $\mathrm{x}$ & $\mathrm{x}$ & 8 \\
\hline Fax & & $\mathrm{x}$ & & $\mathrm{x}$ & & & & & 2 \\
\hline E-mail & $\mathrm{x}$ & $\mathrm{x}$ & & $\mathrm{x}$ & & & $\mathrm{x}$ & $\mathrm{x}$ & 5 \\
\hline Visits & & $\mathrm{x}$ & $\mathrm{x}$ & & $\mathrm{x}$ & $\mathrm{x}$ & & & 4 \\
\hline
\end{tabular}


Table 2 - Q2: How is the information exchanged between your company and the supplier?

\begin{tabular}{|l|c|c|c|c|c|c|c|c|c|}
\hline Company $>$ & $\mathrm{C} 1$ & $\mathrm{C} 2$ & $\mathrm{C} 3$ & $\mathrm{C} 4$ & $\mathrm{C} 5$ & $\mathrm{C} 6$ & $\mathrm{C} 7$ & $\mathrm{C} 8$ & Total \\
\hline Phone & $\mathrm{x}$ & $\mathrm{x}$ & & $\mathrm{x}$ & & & & & 3 \\
\hline Fax & $\mathrm{x}$ & $\mathrm{x}$ & $\mathrm{x}$ & $\mathrm{x}$ & & & & & 4 \\
\hline E-mail & $\mathrm{x}$ & $\mathrm{x}$ & & $\mathrm{x}$ & & $\mathrm{x}$ & $\mathrm{x}$ & & 5 \\
\hline Visits & $\mathrm{x}$ & $\mathrm{x}$ & & & $\mathrm{x}$ & & & $\mathrm{x}$ & 4 \\
\hline EDI & & & & & & & $\mathrm{x}$ & & 1 \\
\hline
\end{tabular}

Table 3 - Q3: Which criteria do you use to choose a supplier?

\begin{tabular}{|l|r|r|r|r|r|r|r|r|c|}
\hline Company > & $\mathrm{C} 1$ & $\mathrm{C} 2$ & $\mathrm{C} 3$ & $\mathrm{C} 4$ & $\mathrm{C} 5$ & $\mathrm{C6}$ & $\mathrm{C7}$ & $\mathrm{C} 8$ & Total \\
\hline In-site analysis & $\mathrm{x}$ & $\mathrm{x}$ & & & & $\mathrm{x}$ & & & 3 \\
\hline ISO 9000 & & $\mathrm{x}$ & & & & & & & 1 \\
\hline Quality & $\mathrm{x}$ & & & & $\mathrm{x}$ & $\mathrm{x}$ & & $\mathrm{x}$ & 4 \\
\hline Reliability & & & & $\mathrm{x}$ & $\mathrm{x}$ & $\mathrm{x}$ & & & 3 \\
\hline Price & & & $\mathrm{x}$ & & $\mathrm{x}$ & $\mathrm{x}$ & & & 3 \\
\hline Delivery & & & & & & $\mathrm{x}$ & $\mathrm{x}$ & & 2 \\
\hline
\end{tabular}

Table 4 - Q4: If you could check your supplier performance continuously, which information would you require to be provided?

\begin{tabular}{|l|c|c|c|c|c|c|c|c|c|}
\hline Company > & $\mathrm{C} 1$ & $\mathrm{C} 2$ & $\mathrm{C} 3$ & $\mathrm{C} 4$ & $\mathrm{C} 5$ & $\mathrm{C6}$ & $\mathrm{C} 7$ & $\mathrm{C} 8$ & Total \\
\hline In-site analysis only & & & & & & & & $\mathrm{x}$ & 1 \\
\hline ISO 9000 & & $\mathrm{x}$ & & & & & & & 1 \\
\hline Production status & $\mathrm{x}$ & & & $\mathrm{x}$ & $\mathrm{x}$ & & & & 3 \\
\hline Shipping status & & & & & & $\mathrm{x}$ & $\mathrm{x}$ & & 2 \\
\hline
\end{tabular}

Table 5-Q5: In case the supplier is placed far away, how would you proceed?

\begin{tabular}{|l|r|r|r|r|r|r|r|c|c|}
\hline Company > & $\mathrm{C} 1$ & $\mathrm{C} 2$ & $\mathrm{C} 3$ & $\mathrm{C} 4$ & $\mathrm{C} 5$ & $\mathrm{C6}$ & $\mathrm{C} 7$ & $\mathrm{C} 8$ & Total \\
\hline Auditing visits & $\mathrm{x}$ & & & $\mathrm{x}$ & & & & & 2 \\
\hline Representatives & & & & & & $\mathrm{x}$ & & & 1 \\
\hline Questionnaires & & $\mathrm{x}$ & & & & & & & 1 \\
\hline Phone contact & & & & $\mathrm{x}$ & $\mathrm{x}$ & & & & 2 \\
\hline Internet & & $\mathrm{x}$ & & & $\mathrm{x}$ & & & & 2 \\
\hline
\end{tabular}

Table 6 - Q6: Do you keep any kind of control on your suppliers products?

\begin{tabular}{|l|c|c|c|c|c|c|c|c|c|}
\hline Company > & $\mathrm{C} 1$ & $\mathrm{C} 2$ & $\mathrm{C} 3$ & $\mathrm{C} 4$ & $\mathrm{C} 5$ & $\mathrm{C} 6$ & $\mathrm{C} 7$ & $\mathrm{C} 8$ & Total \\
\hline Auditing visits & $\mathrm{x}$ & & & & & & & & 1 \\
\hline ISO9000 or equivalent & & $\mathrm{x}$ & $\mathrm{x}$ & & & & & & 2 \\
\hline Quality inspection & $\mathrm{x}$ & & & $\mathrm{x}$ & & & & $\mathrm{x}$ & 3 \\
\hline Suppliers classification & & & & & & & $\mathrm{x}$ & & 1 \\
\hline
\end{tabular}

Table 7 - Q7: Do you keep control on the production process along with your suppliers?

\begin{tabular}{|l|r|r|r|r|r|r|r|r|c|}
\hline Company $>$ & $\mathrm{C} 1$ & $\mathrm{C} 2$ & $\mathrm{C} 3$ & $\mathrm{C} 4$ & $\mathrm{C} 5$ & $\mathrm{C6}$ & $\mathrm{C} 7$ & $\mathrm{C} 8$ & Total \\
\hline Yes & & & $\mathrm{x}$ & & $\mathrm{x}$ & & $\mathrm{x}$ & & 3 \\
\hline No & $\mathrm{x}$ & $\mathrm{x}$ & & $\mathrm{x}$ & & $\mathrm{x}$ & & & 4 \\
\hline
\end{tabular}


Table 8 - Q8: Are the computers in your company connected by a network?

\begin{tabular}{|l|r|r|r|r|r|r|r|r|c|}
\hline Company $>$ & $\mathrm{C} 1$ & $\mathrm{C} 2$ & $\mathrm{C} 3$ & $\mathrm{C} 4$ & $\mathrm{C} 5$ & $\mathrm{C} 6$ & $\mathrm{C} 7$ & $\mathrm{C} 8$ & Total \\
\hline Yes & $\mathrm{x}$ & $\mathrm{x}$ & $\mathrm{x}$ & $\mathrm{x}$ & $\mathrm{x}$ & $\mathrm{x}$ & $\mathrm{x}$ & $\mathrm{x}$ & $\mathbf{8}$ \\
\hline No & & & & & & & & & 0 \\
\hline
\end{tabular}

Table 9 - Q9: Do they have access to the Internet?

\begin{tabular}{|l|r|r|r|r|r|r|r|r|c|}
\hline Company > & C1 & C2 & C3 & C4 & C5 & C6 & C7 & C8 & Total \\
\hline Yes & $\mathrm{x}$ & $\mathrm{x}$ & $\mathrm{x}$ & $\mathrm{x}$ & $\mathrm{x}$ & $\mathrm{x}$ & $\mathrm{x}$ & $\mathrm{x}$ & $\mathbf{8}$ \\
\hline No & & & & & & & & & 0 \\
\hline
\end{tabular}

Table 10 - Q10: Does your company have its own homepage (site)?

\begin{tabular}{|l|r|r|r|r|r|r|r|r|c|}
\hline Company $>$ & $\mathrm{C} 1$ & $\mathrm{C} 2$ & $\mathrm{C} 3$ & $\mathrm{C} 4$ & $\mathrm{C} 5$ & $\mathrm{C} 6$ & $\mathrm{C} 7$ & $\mathrm{C} 8$ & Total \\
\hline Yes & $\mathrm{x}$ & $\mathrm{x}$ & $\mathrm{x}$ & $\mathrm{x}$ & & $\mathrm{x}$ & $\mathrm{x}$ & $\mathrm{x}$ & 7 \\
\hline No & & & & & $\mathrm{x}$ & & & & 1 \\
\hline
\end{tabular}

Table 11 - Q11: Does your company choose your supplier via Internet?

\begin{tabular}{|l|r|r|r|r|r|r|r|r|c|}
\hline Company $>$ & $\mathrm{C} 1$ & $\mathrm{C} 2$ & $\mathrm{C} 3$ & $\mathrm{C} 4$ & $\mathrm{C} 5$ & $\mathrm{C} 6$ & $\mathrm{C} 7$ & $\mathrm{C} 8$ & Total \\
\hline Yes & & & $\mathrm{x}$ & & & $\mathrm{x}$ & & & 2 \\
\hline No & $\mathrm{x}$ & & & & $\mathrm{x}$ & & $\mathrm{x}$ & $\mathrm{x}$ & 4 \\
\hline
\end{tabular}

Table 12 - Companies willing to choose suppliers via Internet.

\begin{tabular}{|l|r|r|r|r|r|r|r|r|c|}
\hline Company $>$ & $\mathrm{C} 1$ & $\mathrm{C} 2$ & $\mathrm{C} 3$ & $\mathrm{C} 4$ & $\mathrm{C} 5$ & $\mathrm{C} 6$ & $\mathrm{C} 7$ & $\mathrm{C} 8$ & Total \\
\hline Yes & $\mathrm{x}$ & $\mathrm{x}$ & & & & $\mathrm{x}$ & $\mathrm{x}$ & $\mathrm{x}$ & 5 \\
\hline No & & & $\mathrm{x}$ & $\mathrm{x}$ & & & & & 2 \\
\hline
\end{tabular}

Table 13 - When choosing a supplier, is it possible to rely on the information provided by the Internet alone?

\begin{tabular}{|l|c|c|c|c|c|c|c|c|c|}
\hline Company $>$ & $\mathrm{C} 1$ & $\mathrm{C} 2$ & $\mathrm{C} 3$ & $\mathrm{C} 4$ & $\mathrm{C} 5$ & $\mathrm{C} 6$ & $\mathrm{C} 7$ & $\mathrm{C} 8$ & Total \\
\hline Yes & & & & & & & & & 0 \\
\hline No & $\mathrm{x}$ & $\mathrm{x}$ & $\mathrm{x}$ & $\mathrm{x}$ & & $\mathrm{x}$ & & $\mathrm{x}$ & 6 \\
\hline
\end{tabular}

Table 14 - Q12: Would it be useful to search databases on the Internet to search for clients and suppliers?

\begin{tabular}{|l|r|r|r|r|r|r|r|r|c|}
\hline Company $>$ & $\mathrm{C} 1$ & $\mathrm{C} 2$ & $\mathrm{C} 3$ & $\mathrm{C} 4$ & $\mathrm{C} 5$ & $\mathrm{C} 6$ & $\mathrm{C} 7$ & $\mathrm{C} 8$ & Total \\
\hline Yes & $\mathrm{x}$ & $\mathrm{x}$ & $\mathrm{x}$ & $\mathrm{x}$ & & $\mathrm{x}$ & & $\mathrm{x}$ & 6 \\
\hline No & & & & & & & & & 0 \\
\hline
\end{tabular}

Table 15 - Q13: Would your company be a future user of the e- commerce?

\begin{tabular}{|l|r|r|r|r|r|r|r|r|c|}
\hline Company $>$ & C1 & C2 & C3 & C4 & C5 & C6 & C7 & C8 & Total \\
\hline Yes & $\mathrm{x}$ & & $\mathrm{x}$ & & & $\mathrm{x}$ & $\mathrm{x}$ & & 4 \\
\hline Perhaps & & $\mathrm{x}$ & & & & & & & 1 \\
\hline Not yet & & & & $\mathrm{x}$ & $\mathrm{x}$ & & & $\mathrm{x}$ & 3 \\
\hline
\end{tabular}




\section{CONCLUSIONS}

From the analysis of this market survey it is possible to draw some (still) preliminary conclusions:

(i) the use of the e-mail/Internet is a reality for a significant number of the surveyed companies - which is relevant for a DC - based on the evidences arising from the tables $1,2,8,9,10$;

(ii) companies see the use of the e-commerce technology as an effective opportunity for increasing some of their commercial activities (tables 5, 12, 14 and 15), although it does not seem to replace entirely other means of contacting suppliers and clients (table 13) even in the future;

(iii) the e-commerce has some inherent restrictions which requires some type of complementary actions to be performed (lying out of the use of the ecommerce technology) - tables 3, 6;

(iv) the companies seem to be interested in controlling their suppliers performances more closely which suggests a possible use of specific software packages devised for this purpose to be used via the Internet (supported by the combination of the results from tables 4, 5, 7, 11, 12).

The use of the Internet as the vehicle for operating the e-commerce seems to be the best alternative the companies are considering at the moment (instead of using dedicated EDI technology on a company-to-company communication basis). Most of the surveyed companies referred to be at least interested in increasing the use of the e-commerce. Nevertheless this action depends on the very nature of their business processes thus leading some companies to approach the world of the e-business more intensively than others.

At last it can be said that from the point of view of using the e-business techniques the surveyed companies seem to be prepared to join the virtual enterprising process. As we can consider the group of the surveyed companies quite representative from the local reality it appears the problem of using the e-commerce technology will not be the major problem regarding the establishment of effective virtual enterprises in Brazil.

However, more conclusive results should consider a bigger number of companies and a broader vision on its specific branches and specific activities.

\section{ACKNOWLEDGEMENTS}

The research previously presented was granted by the Commission of the European Communities under contract $\mathrm{n}^{\circ} 961934$ - Project Easy-to-use Procedures for Quality Management Tailored for Small and Medium-sized Enterprises (ProSME) from the INCO-DC Programme.

\section{REFERENCES}

1. Brito, G. - A market in ebulition. Internet Business 2 (20), April, 1999.

2. Vargas, N.; Diefenthaler,G.; Pereira, J.A.G.; Salgado, E. - Critical questions to be faced by Brazil to avoid being a coadjutant in the digital era. Revista Amanhã, January, 2000. pp. 40-49 (in Portuguese).

3. Vaz, R. C. R. - Developer's Magazine, September 1998. 